\title{
Project Managers as Knowledge Workers: Competencies for Effective Project Management in Developing Countries
}

\author{
Armstrong Amoah ${ }^{1, *(D)}$ and Frederic Marimon ${ }^{2, *(D)}$ \\ 1 Faculty of IT Business, Takoradi Campus, Ghana Communication Technology University, \\ Takoradi P.O. Box MC 3262, Ghana \\ 2 Department of Economy and Business Organization, Universitat Internacional de Catalunya, C/Immaculada, \\ 22, 08017 Barcelona, Spain \\ * Correspondence: aamoah@gctu.edu.gh (A.A.); fmarimon@uic.es (F.M.)
}

Citation: Amoah, Armstrong, and Frederic Marimon. 2021. Project Managers as Knowledge Workers: Competencies for Effective Project Management in Developing Countries. Administrative Sciences 11: 131. https://doi.org/10.3390/ admsci11040131

Received: 30 September 2021 Accepted: 5 November 2021 Published: 11 November 2021

Publisher's Note: MDPI stays neutral with regard to jurisdictional claims in published maps and institutional affiliations.

Copyright: (c) 2021 by the authors. Licensee MDPI, Basel, Switzerland. This article is an open access article distributed under the terms and conditions of the Creative Commons Attribution (CC BY) license (https:// creativecommons.org/licenses/by/ $4.0 /)$.

\begin{abstract}
Studies have shown that project managers are responsible for the successful management of various projects. Increasingly, this success depends on the project manager being a knowledge worker (KW) -i.e., possessing and utilizing both "hard" and "soft" skills/competencies to manage assigned projects. Nonetheless, there has not been enough studies on what these competencies are, especially in the context of developing countries (DCs). This study, therefore, seeks to conceptualize project managers as KWs by identifying the key competencies and their relationships needed to effectively manage projects in DCs. To achieve this objective, a survey was conducted among 112 project management (PM) practitioners in Ghana. The opinions from the respondents were edited, summarized and categorized by creating word queries, thus, making it easier to make deductions from them. Finally, content analysis was conducted to help establish links in the responses so as to deduce appropriate recommendations. The findings provide a set of "soft" and "hard" skills/competencies and their unique combinations for effective PM in DCs. The primary contribution of this study stems from highlighting the key competencies that project managers need to ensure effective PM in DCs, thus, helping these countries to make a more efficient use of their scarce resources.
\end{abstract}

Keywords: competencies; knowledge workers; project oriented organizations; project management; developing countries

\section{Introduction}

Projects are used in all economic and non-economic fields as means of organizing activities aimed at achieving a desired objective. They serve as the basis for creating and dealing with change and are used to implement strategies (Cleland and Gareis 2006). What is remarkable is that irrespective of how you define projects, the greater attention is being put on the project manager. Without a qualified project manager, the project oriented organization will not achieve project management (PM) success. The project manager is a leader and a team member. Therefore, the future of the project depends on his ability, experience and personal features (Igielski 2014).

In most project oriented organizations (organizations that have their activities geared towards projects), project managers are accountable for the successful management and execution of various projects (Bourne and Walker 2004). Until recently, many of the initiatives for improving the practice and profession of PM-towards achieving PM success-have been focused on enhancing techniques and methods associated with skills that included effective management of time, cost and scope. The Project Management Institute's guide to the PM Body of Knowledge (PMBOK) tends to be primarily concerned with management competencies (craft) and the "hard" skills expected of practicing PM professionals with knowledge areas such as project human resource management and project communication 
management (the essential relationship-focused areas) relegated to secondary (and less important) roles (PMI 2002, 2008).

However, research show that achieving PM success depends on the project manager being a knowledge worker (KW) -i.e., possessing and utilizing both "hard" and "soft" skills and competencies to manage assigned projects. The project manager needs to demonstrate flexibility and competence in many areas: introverted and reflective and extroverted and social behaviors (Bourne and Walker 2004). The management of all projects, especially those in developing countries (DCs) demand the application of the required competencies that go beyond technical expertise only, but the ability to manage scarce resources and monitor time overruns and other ad hoc situations, while dealing with employees and other organizational issues at the same time (Abbasi and Al-Mharmah 2000; PMI 2017).

Ofori (2013) observed that most of the policies introduced by various governments in DCs are usually converted to programs and projects. The need for effective PM in DCs has therefore become more relevant in dealing with the enormous task of managing the level of poverty in these countries. Effective PM implies that the management of the project should lead to meeting stakeholder requirements, although these requirements may differ among the stakeholders (Chan et al. 2004). Currently, most PM practices of many project oriented organizations in DCs do not always meet this criteria. The major challenge has been the kinds of skills and competencies possessed by project managers in these countries (Forcada et al. 2008; Osei-Kyei and Chan 2017). In the words of Twumasi-Ampofo et al. (2014), the root causes of the abandonment of most public housing projects in DCs are as a result of the inability of many project managers to act as KWs during the planning and execution of complex projects.

In an effort to improve upon the effectiveness of PM, many DCs have resorted to the use of foreign PM experts (Rondinelli 1993; Rahman and Ayer 2017), however, the results have mostly been unsatisfactory (Othman and Ahmed 2013). Further research has shown that as a feature of most projects in DCs, they are relatively complex, have many participants and usually have an unstructured outline; requiring very peculiar and competent project managers to be able to successfully manage (Cannon 1994). Aligned with these assertions, Ofori (2013) advised that managers of projects in DCs need to possess a mixture of some peculiar "soft" and "hard" skills to be able to effectively manage projects in these countries.

Nonetheless, there has not been specific studies on the actual skills/competencies that are required for effective PM by project managers in DCs (Crawford 2005; Olateju et al. 2011; Ofori 2013). The objectives of this study therefore seeks to (1) conceptualize project managers as knowledge workers, (2) come out with the skills/competencies required of project managers for effective PM in DCs and, based on these, (3) draw policy guidelines with a special focus for DCs.

The remainder of the paper is structured as follows. We present a theoretical background of our study. Next, the methodologies used in this research are explained, followed by a presentation of the results and discussion, and the implications of the findings. The paper ends with the concluding remarks, limitations and suggestions for future research.

\section{Theoretical Background}

\subsection{Project Managers as Knowledge Workers}

In his book, The Landmarks of Tomorrow, Peter Drucker (1959) first coined the term "knowledge worker". The author defined KWs as high-level workers who apply theoretical and analytical knowledge, acquired through formal training, to develop products and services. KWs usually have the ability to solve complex problems or develop new products or services in their fields of expertise. However, in PM KWs are considered to refer to any worker who receive information, assimilate it, and decide what to do and execute decisions based on the knowledge that comes from the information received (Olomolaiye and Egbu 2004). Therefore, they are mainly characterized by their knowledge rather than their ability 
to perform manual labor. They perform best when empowered to make the most of their deepest skills (Serrat 2017).

Ly et al. (2005) argued that project managers fit into the definition of KWs. The authors went further to justify their claim by stating that project managers are individuals with very special skills and training. In the construction industry, they manage, coordinate and supervise the construction process from the conceptual development stage through final construction on a timely and economical basis (Covey 2004). They are responsible for coordinating and managing people, materials, equipment, budgets, schedules, contracts and safety of employees and the general public (Bureau of Labor Statistics 2005); they usually manage themselves, are good role models, select the right people with appropriate skills and experience, and know how to manage concerns of team members (Masterman 2002).

Olomolaiye and Egbu (2004) further added that project managers fall under the umbrella of KWs as they are natural problem solvers, they use their intellect rather than their manual skills to earn a living, they require high level of autonomy, they are very interested in the quality of their judgment rather than the speed of work and have more allegiance to their area of specialist expertise or community of practice more than to their employers. In addition, project managers usually know more about their job than other members in the organization, they use knowledge and information to create deeper knowledge and information, they cherish challenging tasks and require a habit of continuous learning due to their recognition of the shelf-life of knowledge and possess uncodified knowledge which is difficult to duplicate (Muo 2013). The fact that project managers possess factual and theoretical knowledge, access and apply information, communicate with project stakeholders and motivate project team members makes them KWs (Turriago-Hoyos et al. 2016).

\subsection{Key Competencies for Effective Project Management}

In PM, competence is defined as key cluster of related knowledge, abilities or skills, experience, attitudes and other personal attributes and features that are needed by a project manager in order to deliver high quality project performance (Sebt et al. 2010). It involves a set of related learning, mentalities, aptitudes and other individual characteristics that largely impacts on one's job (Barna 2013). Crawford (2005, p. 12) contended that "competence could be inferred from attributes, which includes knowledge, skills and experience, personality traits, attitudes, and behaviors".

Competencies of project managers have been categorized differently by various scholars (Thal and Bedingfield 2010). According to the PMI (2017), the competencies needed by project managers to perform their duties successfully can be defined using three different dimensions: PM knowledge, PM performance and personal competencies. Adding to this list, the international project management association (IPMA) emphasized in their individual competence based report (IPMA 2006) that technical competence, behavioral competence and contextual competence are crucial for effective PM. Nonetheless, project managers are expected to apply a combination of ethical, interpersonal and conceptual skills to be able to analyze situations and interact properly. Some of these ethical, interpersonal and conceptual competencies includes leadership, team building, motivation, communication, decision making, political and cultural awareness, negotiation, trust building, conflict management and coaching (PMI 2013; Amponsah 2010).

Kerzner (2000) stated that the development of PM has altered the kind of competence needed to become an effective project manager. During the early periods of PM, a lot of priority was given to only technical skills but as time went on, managerial and behavioral skill became equally relevant since the composition of the project team changed from being solely engineering people. However, contemporary PM demands the application of different set of skills and competencies because the objectives of the business in these current circumstances are to some extent more relevant than the technical objectives. Project managers are currently supposed to concentrate more on making business decisions than just technical ones. They are supposed to place their roles as managers and leaders ahead 
of any other roles they may have (PMI 2013). Murch (2001) however disagreed with these assertions by suggesting that project managers are supposed to have enough technical competence and understanding to be able to effectively execute their tasks. He stressed that it even becomes more relevant when managing construction projects, because these kinds of projects are usually more technical and complex in nature; requiring enough engineering knowledge and the application of scientific principles. Nonetheless, on a relatively different note, other authors have suggested competencies such as financial management (Michalski et al. 2018), organizational governance (Kalodimos 2017) and risk management (García-Piqueres et al. 2019; Lozano-Torró et al. 2019; Klakegg 2016) as relevant for effective PM.

To arrive at an ideal situation concerning the mixture of competencies that project managers, as KWs need to effectively manage assigned projects, various authors have come up with various frameworks and their usefulness for building necessary competence towards PM success for example (Morris 2010; Bartoška et al. 2012; Madter et al. 2012). However, for the purpose of this study we choose the competence models of the International Project Management Association (IPMA) (2006) and Jałocha et al. (2014) to build upon it a competence typology for project managers (Table 1). In our framework, we have distinguished two roles (manager in general and project manager) and their corresponding key competencies (divided into contextual, behavioral and technical competencies).

PM has been recognized as a driver of economic development in DCs. Consequently, several programs including real estate development, event planning, product development and infrastructure development-especially those tied to foreign aid from development partners in DCs, all lay heavy emphasis on the use of PM as a tool to optimize the rate of success.

However, the way and manner projects are managed in DCs is problematic. The way projects are funded in many DCs for example creates problems for the responsible public institutions and the sponsors as well. The percentage of funding that comes from grants and aids from donor agencies for projects in DCs is relatively high, to the extent that these donors are now referred to as development partners; showing the extent to which the DCs' developmental agenda has relied on donor supports (Ofori 2013). The challenge is that in most cases, these grants are not without conditions (normally unfavorable), which impact on the developmental project right from the conception, planning, execution and the implementation stages. By embarking on projects based on donors recommendations rather than what the citizens actually need, donor interests actually becomes an impeding force towards the scope definition, starting, execution and implementation of projects that will have significant impact on the life of the citizens in DCs (Ofori-Kuragu et al. 2016). In some instances, some projects would have to be cancelled due to unfavorable conditions from donors that conflict with the culture and traditions, the starting dates, hierarchy, taboos and other important issues that often impact on PM success in DCs (Awuah 2009).

Ika and Hodgson (2010) added that PM in DCs are confronted with various challenges. These challenges they described as "the notorious and critical implementation problems," some easy to deal with whiles others are almost uncontrollable. Challenges such as bad governance and conflicts, inadequate PM capacity and "dirty" politics that hurts developmental projects are usually mentioned (Williams 2011; Bokor 2011). In their article on construction delays, Fong et al. (2006) observed that many projects in DCs encounter considerable time and cost overruns, fail to meet their intended benefit or even fully aborted and rejected before or after their completion. Generally, the construction industry in DCs for example, fail to meet expectations of governments, clients and society as a whole (Ofori 2013; Jekale 2004). Providing further explanation to this phenomena, Olateju et al. (2011) mentioned that in many instances, governments of DCs have attempted to embark on too many projects than they can fund, and this usually leads to incomplete projects. Other factors such as structural challenges, institutional challenges, managerial/organizational challenges, cultural blocks, lack of competent staff, unfavorable economic conditions, weak 
political institutions and overreliance on religious beliefs have also been mentioned (Ika 2012; Ibenta 2012).

Table 1. Key competencies for managers and project managers.

\begin{tabular}{|c|c|c|}
\hline Contextual Competence & Behavioral Competence & Technical Competence \\
\hline \multicolumn{3}{|c|}{ Managers in General } \\
\hline $\begin{array}{l}\text { Permanent organization } \\
\text { - } \quad \text { Business: competence on } \\
\text { the branch/sector to } \\
\text { which the organization } \\
\text { belongs } \\
\text { - } \quad \text { Systems, production and } \\
\text { technology } \\
\text { - } \quad \text { Personnel management } \\
\text { - Health, security, safety } \\
\text { - } \quad \text { Gend environment } \\
\text { - } \quad \text { General legal knowledge }\end{array}$ & $\begin{array}{ll}\text { - } & \text { Leadership } \\
\text { - } & \text { Engagement and } \\
\text { - } & \text { motivation } \\
\text { - } & \text { Asserf-control } \\
\text { - } & \text { Relaxation } \\
\text { - } & \text { Openness } \\
\text { - } & \text { Creativity } \\
\text { - } & \text { Result orientation } \\
\text { - } & \text { Efficiency } \\
\text { - } & \text { Consultations } \\
\text { - } & \text { Negotiations } \\
\text { - } & \text { Conflicts and crises } \\
\text { - } & \text { Reliability } \\
\text { - } & \text { Values appreciation } \\
\text { - } & \text { Ethics }\end{array}$ & $\begin{array}{ll}\text { - } & \text { Professional competence } \\
\text { - } & \text { Fin subject area } \\
\text { - } & \text { Inter-organizational } \\
& \text { learning } \\
\text { - } & \text { Sound decisions making } \\
\text { - } & \text { Long range thinking: } \\
& \text { ability to recommend } \\
\text { effective strategies }\end{array}$ \\
\hline \multicolumn{3}{|c|}{ Project Managers } \\
\hline $\begin{array}{ll}\text { - } & \text { Project orientation } \\
\text { - } & \text { Program orientation } \\
\text { - } & \text { Portfolio orientation } \\
& \text { Project, program and } \\
\text { - } & \text { Pertfolio implementation } \\
\text { - } & \text { Business } \\
\text { - } & \text { Systems, products and } \\
& \text { technology } \\
\text { - } & \text { Personnel management } \\
\text { - } & \text { Health, security, safety } \\
\text { - } & \text { and environment } \\
\text { - } & \text { Legan }\end{array}$ & $\begin{array}{ll}\text { - } & \text { Leadership } \\
\text { - } & \text { Engagement } \\
\text { - } & \text { Assertiveness } \\
\text { - } & \text { Relaxation } \\
\text { - } & \text { Openness } \\
\text { - } & \text { Creativity } \\
\text { - } & \text { Results orientation } \\
\text { - } & \text { Efficiency } \\
\text { - } & \text { Consultation } \\
\text { - } & \text { Negotiation } \\
\text { - } & \text { Conflict and crisis } \\
\text { - } & \text { Reliability } \\
\text { - } & \text { Values appreciation } \\
\text { - } & \text { Ethics }\end{array}$ & $\begin{array}{ll}\text { - } & \text { PM success } \\
\text { - } & \text { Project requirements and } \\
\text { - } & \text { Risk and opportunity } \\
\text { - } & \text { Quality } \\
\text { - } & \text { Project organization } \\
\text { - } & \text { Teamwork } \\
\text { - } & \text { Problem resolution } \\
\text { - } & \text { Project structures } \\
\text { - } & \text { Scope and deliverables } \\
\text { - } & \text { Time and project phases } \\
\text { - } & \text { Resources } \\
\text { - } & \text { Cost and finance } \\
\text { - } & \text { Procurement and } \\
& \text { contract } \\
\text { - } & \text { Changes } \\
\text { - } & \text { Control and reports } \\
\text { - } & \text { Information and } \\
& \text { documentation } \\
\text { - } & \text { Communication } \\
\text { - } & \text { Start-up } \\
\text { - } & \text { Close-out } \\
& \text { Ability to work under } \\
& \text { time pressure }\end{array}$ \\
\hline
\end{tabular}

Source: Self-devised based on IPMA (2006) and Jałocha et al. (2014).

Long et al. (2008) therefore recommended that project managers in DCs need to act as KWs-i.e., use a mix of both "hard" and "soft" skills and competencies to manage assigned projects, which will help to improve the quality of PM in these countries. Sebt et al. (2010) added that due to the complex nature of projects in DCs, project managers in these countries will need to have the appropriate mixture of knowledge, performance and personal competencies to be more efficient and competitive. Nonetheless, for every project in DCs, the project manager is expected to show higher levels of engagement, 
commitment, contribution and understanding of the project environment than other project team members to execute the project successfully (Hölzle 2010).

\section{Materials and Methods}

\subsection{Data Collection and Sampling}

For the purposes of this study, a survey was conducted among certified PM practitioners in Ghana. The profile of the practitioners included government officials, heads of public and private institutions and civil servants who give project contracts, contractors and managers, managers of non-governmental organizations and employees of project oriented organizations and other individuals who are certified PM practitioners in Ghana. The survey was self-administered to the executives of the project PMI in Ghana for onward distribution to their members on the 14th of December, 2019. This was conducted after a letter of request explaining the purpose of the study and asking for their acceptance to participate in the survey had already been issued. A positive response from the PMI was received on the 26th of November, 2019. In the quest to acquire the minimum sample size of 112 , the authors distributed the survey to a total number of 130 respondents. In all, 119 responses (representing a response rate of $91.5 \%$ ) were returned after completion. From them, 100 were dully completed and consequently, were valid for the analysis.

\subsection{Measures}

The survey that was distributed to PM experts was designed using English language and was made up of three sections. Using the competency profiles suggested by the IPMA (2006); Jałocha et al. (2014) for project managers in Table 1 under Section 2.2; adjusting to suit the purpose of this study, the first section of the survey asked PM experts to suggest which of the skills and competencies provided by the aforementioned authors is required of project managers as KWs to effectively manage projects in DCs. Again, deploying the open-ended questioning approach, the respondents were asked in the same section to suggest competencies—not necessarily based on thoses provided by IPMA (2006); Jałocha et al. (2014) - that they believe (based on their experience as PM professionals) are required of project managers to effectively manage projects in DCs. Section two of the survey asked respondents to suggest a combination of the competencies provided by the IPMA (2006); Jałocha et al. (2014) and the ones they have suggested (in section one of the survey), that project managers need to possess in order to effectively manage projects in DCs. The final section of the survey however asked the PM experts to suggest some PM activities that project managers need to embark on with their competencies in order to achieve PM effectiveness in DCs.

\subsection{Data Analysis Procedure}

Data obtained from the survey were analyzed using excel and Nvivo v11 software for Windows. First, the responses from the survey participants were exported into an excel file from Google forms. Next, the volume of the raw data was reduced by cleaning (deleting redundant and unwanted information) and summarizing. These activities were carried out to help make sense of the huge amount of data collected. The now accurate data was then uploaded unto the Nvivo v11 software to help identify significant patterns, draw meaning from the data and subsequently build a logical chain of evidence.

To begin with the actual analysis, the Nvivo v11 software was used to identify the frequency of suggestion of various competencies suggested by the respondents in section one of the survey. This was performed by creating word queries using the competency profiles suggested in the review. The results were used to create a frequency table with various skills and competencies needed for effective PM in DCs and their frequency of suggestions. For the responses obtained from the second section of the survey, similar suggestions of combination of competencies were grouped as one category. Therefore, if a group of respondents suggest the same or similar combination of competencies, they are put together as one category, etc. In the end, three different combinations-representing 
three different categories were obtained. Finally, the analysis of the responses from the third section of the survey followed the same procedure as that of the second section. In all, three categories were also obtained from responses for the third section of the survey. Consequently, content analysis was conducted to help link responses in the final section of the survey to those of the second, thus, helping to deduce appropriate recommendations from them.

\section{Results and Discussion}

The survey on the competencies needed by project managers to effectively manage projects in DCs first asked the PM experts to suggest the important skills/competencies that they believe is required of project managers, as KWs to be able to manage projects effectively in DCs.

Generally, there was consensus among the PM experts with about 56 (18.7\%) frequency of suggestion that the ability to communicate effectively is the most important competence needed by project managers. Very close to communication skills are leadership skills, technical skills, project team management and project risk management competencies with $37(12.5 \%), 27(9.1 \%), 26(8.8 \%)$ and $21(7.1 \%)$ frequencies of suggestions, respectively. It is notable that other competencies such as negotiation $15(12.5 \%)$, strategizing and planning $13(4.4 \%)$, organization $11(3.7 \%)$, time management $10(3.4 \%)$, general PM knowledge $9(3.0 \%)$, cost management $9(3.0 \%)$, decision making $9(3.0 \%)$, critical thinking $8(2.7 \%)$, procurement and contract management $7(2.4 \%)$ and conflict management $7(2.4 \%)$ were also relatively frequently suggested by the PM experts as relevant for effective PM in DCs. Table 2 provides the details of various skills/competencies, their frequency of suggestion and rank in order of importance by the PM experts who participated in the survey.

Table 2. Skills/competencies and their frequency of suggestion.

\begin{tabular}{|c|c|c|c|}
\hline Competencies & $\begin{array}{c}\text { Frequency of } \\
\text { Suggestion }\end{array}$ & Percent (\%) & $\begin{array}{c}\text { Rank } \\
\text { (Importance) }\end{array}$ \\
\hline Communication Skills & 56 & 18.90 & 1 \\
\hline Leadership Skills & 37 & 12.50 & 2 \\
\hline Technical Expertise & 27 & 9.10 & 3 \\
\hline Project Team Management & 26 & 8.80 & 4 \\
\hline Project Risk Management & 21 & 7.10 & 5 \\
\hline Negotiation Skills & 15 & 5.10 & 6 \\
\hline Strategizing and Planning & 13 & 4.40 & 7 \\
\hline Organizational Skills & 11 & 3.70 & 8 \\
\hline Time Management & 10 & 3.40 & 9 \\
\hline General PM Knowledge & 9 & 3.00 & 10 \\
\hline Decision Making & 9 & 3.00 & 10 \\
\hline Cost and Financial Management & 9 & 3.00 & 10 \\
\hline Critical Thinking & 8 & 2.70 & 13 \\
\hline Project Procurement and Contract Management & 7 & 2.40 & 14 \\
\hline Conflict Management/Problem Solving & 7 & 2.40 & 14 \\
\hline Interpersonal Relationship Management & 5 & 1.70 & 16 \\
\hline Legal Expertise & 3 & 1.00 & 17 \\
\hline Data Analysis and Interpretation & 3 & 1.00 & 17 \\
\hline Innovativeness & 3 & 1.00 & 17 \\
\hline Evaluation and Control & 3 & 1.00 & 17 \\
\hline Adaptability & 3 & 1.00 & 17 \\
\hline Supervision & 3 & 1.00 & 17 \\
\hline Proactiveness & 2 & 0.70 & 23 \\
\hline Records Keeping & 2 & 0.70 & 23 \\
\hline Feedback Management & 1 & 0.30 & 25 \\
\hline Emotional Intelligence & 1 & 0.30 & 25 \\
\hline Critical Thinking & 1 & 0.30 & 25 \\
\hline Prioritization & 1 & 0.30 & 25 \\
\hline Delegation & 1 & 0.30 & 25 \\
\hline Total & 297 & 100.00 & \\
\hline
\end{tabular}

These findings (from Table 2) closely validates the suggestions of Amponsah (2010), the PMI (2013) and the IPMA (2006) on the competences needed by project managers 
to effectively manage projects. Therefore, the competencies identified are reasonably supported and could therefore be potentially useful for further development for use by PM practitioners. That is, while the knowledge of other related competencies might help in delivering some required level of managerial performance, the knowledge of the competencies herein outlined is what "PM experts" expect project managers to have towards achieving effective PM in DCs. The findings therefore provide a pragmatic base on which project managers can improve their knowledge and skills in the key competencies identified, to be able address some of the PM challenges highlighted by Williams (2011) and Bokor (2011) in their respective studies. It is notable however that there are some differences found in our findings compared to similar studies in the literature. Specifically, competencies such as technical skills (Murch 2001), financial management (Michalski et al. 2018), organizational governance (Kalodimos 2017) and risk management (García-Piqueres et al. 2019; Lozano-Torró et al. 2019; Klakegg 2016) were ranked as very relevant for effective PM. These disparities are understandable since these studies were conducted in contexts different from ours (DCs).

Again, the PM experts were asked to suggest a combination of competencies that they deem fit for project managers as KWs who want to achieve PM effectiveness in DCs. The consensus did re-emphasize the relevance of the findings and the statement below best captures some of the very interesting views expressed. One group of the experts (category 1) stated that:

"To achieve PM effectiveness, project managers need to have a mix of technical competence, leadership skills, critical thinking ability, project team management, strategy development, communication and decision making competence".

The same group of respondents added that if the projects to be managed are in DCs, the project manager will need an additional mix of competencies including;

"Risk management, project cost and financial management, project schedule management, project stakeholder engagement competencies and negotiation skills".

Again, category 1 experts recommended that aside having these competencies, project managers need to undertake some of the activities below to able to achieve PM effectiveness:

"Consider stakeholders requirements, create project team, create project risk response team, create and formalize PM roles, create and align leadership competencies with technical competencies, and deploy acceptable scheduling standards for technical tasks, employ qualified, experienced and competent PM personnel, train employees and supervisors before start of the project and continuously inspect ongoing projects.

Another group of experts (category 2) wrote that:

"Generally, for effective PM, the project manager need to have a combination of both "soft" and "hard" skills. Specifically, these skills/competencies should include general knowledge in PM, time management, risk management, human resource management competencies and expertise in information communication technology (ICT). However, a combination of competences such as project planning and organization, conflict management and problem solving, project procurement and contract management competencies, data analysis and interpretation skills and legal expertise are needed for the purposes of PM in DCs".

The respondents again suggested some activities that need to be embarked on by project managers in order to effectively manage an assigned project. The activities include:

"Establish clear project vision and mission, adopt better scheduling standards, develop leadership and technical competencies, clarify project roles and responsibilities, communicate early and often, monitor each progress and manage risk, communicate with project team and beneficiary communities, check the competence and materials of the contractor, involve conflict resolution team in land disputes, investigate any complaint of improper tendering and procurement and involve stakeholders in all stages of the project". 
Finally, the last group (category 3) of the respondents also contributed that:

"Project managers need a mix of supervisory, interpersonal relationships and record keeping skills, ability to prioritize, effective delegation and change management. Furthermore, for the purposes of achieving PM effectiveness in DCs, a combination of competencies such as project monitoring, evaluation and control competencies, project stakeholder management, feedback management competencies, emotional intelligence, proactiveness and innovativeness, ethical and personal integrity recommended for project managers".

The group also suggested some activities that project managers need to undertake with their competencies to be able to manage projects effectively. The activities include:

\begin{abstract}
"Define the scope and objectives of the project and brief the project team on these objectives, ensure community participation, provide insurance for the project, verify employees' qualifications, provide technical input to project specification., assist tender committee in evaluation., identify stakeholders and their requirements, adopt the appropriate mode of communication, set rules on site and using the right PM methodologies, prepare detailed procedures of work breakdown structures, provide adequate duration for all deliveries, ensure safety standards meets international requirement and coordinate activities of various sections of the project oriented organization".
\end{abstract}

From these suggestions of skills and competencies and their combination by respondents for project managers who want to be effective in the management of project assigned to them, one could observe their alignment with those recommended by Bartoška et al. (2012); Madter et al. (2012); IPMA (2006) and Jałocha et al. (2014). Again, with these suggested competencies and activities, PM challenges that are associated with project planning, deployment of project managers and job-matching, time and cost overruns, structural challenges, institutional challenges, managerial/organizational challenges, lack of competent staff and overreliance on religious beliefs (Ofori 2013; Olateju et al. 2011; Ika 2012; Ibenta 2012) in DCs can be addressed.

\title{
Implications of Findings
}

From the findings obtained in this study, some managerial and policy implications can be drawn for effective PM in DCs.

First, project oriented organizations need to make it as a matter of policy to employ project managers who have the competence to manage projects in DCs. The project manager to be selected to lead projects in DCs should be required to exhibit sound knowledge of the culture, values, morals and the orientation of the clients and the stakeholders of the projects in these countries. Again, they must be required to possess some of the specific competencies discussed in this study. Project oriented organizations need to further polish the competencies of their project managers by offering them periodic training and refresher courses on the changing PM environment of DCs.

Other findings in this study emphasize the fact that project oriented organizations need to come to the realization that there are some specific competencies that are desired from project managers in order to effectively manage projects in DCs; and that most of these competences are developing-country-specific and not required in any other PM environment. What needs to be understood here is that these competencies are not only "hard skills" (technical competences) but a combination of both "hard" and "soft" skills (ethical, interpersonal and conceptual skills).

Additionally, top managers of project oriented organizations in DCs need to use the competency-profiles created in this study to facilitate the establishment of continuing professional development programs for their project managers to ensure that they maintain the currency and scope of the knowledge and skills that are needed to manage projects effectively in DCs. In this context, the competency profiles developed in this study should be used as a foundation for developing a knowledge-based tool-kit or a skills charting competency mapping processes for which project managers in DCs can review, plan and 
undertake self-assessment of the key knowledge and skills they require to develop their managerial excellence.

Finally, international project managers need to avoid the direct deployment of complex PM techniques and activities that have been used to manage projects in developed countries to manage projects in DCs. Managers of projects in DCs need to adopt some of the DCsspecific PM practices that have been discussed in this study. Consequently, the over reliance on advanced countries for their expertise to manage projects in DCs need to be reconsidered since their techniques and practices have almost always been difficult to implement due to cultural differences.

\section{Conclusions}

Studies have shown that projects in DCs are relatively complex, have many participants and usually have an unstructured outline; requiring project managers who are KWs to deploy unique competencies to be able to effectively manage (Cannon 1994). However, there has not been enough studies on what these so-called unique competencies are (Crawford 2005; Olateju et al. 2011; Ofori 2013), especially in the context of DCs. This study therefore seeks to identify key competencies and their relationships for effective PM in DCs.

Under these circumstances, the original contribution of this study is geared towards building a competency profile for effective PM in DCs through the recommendations made under the discussion of the implications of the findings. In the discussion section, this study makes it clear the kind of competencies and skills that are needed by project managers (in the contemporary and challenging environment of DCs) to effectively manage an assigned project. These competency profiles can be used in practice by project oriented organizations to employ project managers with the appropriate competencies for managerial positions. Therefore, the profile could be used to develop an in-service decision-making tool to help top managers who may want to deploy other categories of staff such as deputy project manager and/or project coordinator who demonstrate some reasonable understanding of the relevant knowledge and skills to assist the project manager. For instance, if the project manager becomes indisposed and a replacement is needed as quickly as possible, the checklist developed in this study could be used to quickly identify an appropriate replacement.

Again, studies show that one of the major problems often faced by panelists in many project oriented organizations during interviews is to have an objective framework on which to make informed and uniform decisions (Lyons 2003). The findings in this study could therefore be used as an "interviewing checklist" by top managers of project oriented organizations so that when selecting potential project managers, the interview panel will have a working framework on which to ask questions and also score points for the project managers with the appropriate competencies and skills.

Furthermore, in many DCs, PM training are not specific and offer very little room for generating the professional development of project managers. In many DCs, very little emphasis is placed on curriculum development towards generating PM activities that are required for effective PM (Ahadzie et al. 2009). With the increasingly strategic importance of projects in many DCs both in terms of scope and the potential for advancement of improved managerial practices, these findings could be used among other things, as a foundation for developing any future specific curricula for PM education and training in these countries.

Another contribution of this study is the fact that the findings of this research will help improve PM success rates in DCs. Understanding the competencies for effective PM in these countries will help both policy makers and managers of project oriented organizations to know who to assign a particular project, thus, helping to deal with PM challenges faced by these countries. 


\section{Limitations and Suggestions for Future Research}

First, for purposes of data collection, the opinions of PM experts in Ghana were used in this study. Therefore, inferring the findings from this study to all DCs can be problematic. Future research might consider incorporating more DCs for better inference as well as for comparing the results among different countries and regions.

Again, since the demand for effectiveness of project managers may vary from one project oriented organization to another; it is recommended that future research be carried out to determine the demand of each type of project oriented organization in any kind of industry for the effectiveness of project managers separately.

Author Contributions: Conceptualization, A.A. and F.M.; methodology, A.A. and F.M.; software, A.A.; validation, A.A.; formal analysis, A.A.; investigation, A.A.; resources, A.A.; data curation, A.A.; writing—original draft preparation, A.A.; writing—review and editing, F.M.; visualization, F.M.; supervision, F.M.; project administration, F.M. All authors have read and agreed to the published version of the manuscript.

Funding: There is no funding for this research.

Data Availability Statement: All the data, models, or code that support the findings of this study are available from the corresponding author upon reasonable request.

Acknowledgments: This paper was written using responses from members of the project management institute and other project management experts in Ghana. The authors are grateful to them.

Conflicts of Interest: The authors declare no conflict of interest with respect to the research, authorship, and/or publication of this article.

\section{References}

Abbasi, Ghaleb Y., and Hisham Al-Mharmah. 2000. Project management practice by the public sector in a developing country. International Journal of Project Management 18: 105-9. [CrossRef]

Ahadzie, Divine K., David Proverbs, Paul O. Olomolaiye, and Nii Ankrah. 2009. Competencies required by project managers for housing construction in Ghana: Implications for CPD agenda. Engineering, Construction and Architectural Management 16: 353-75. [CrossRef]

Amponsah, Richard. 2010. Improving Project Management Practice in Ghana with Focus on Agriculture, Banking and Construction Sectors of the Ghanaian Economy. Ph.D. thesis, School of Property, Construction and Project Management, RMIT University, Melbourne, Australia.

Awuah, Mike. 2009. Third Encounter: Book 111-Starting a Project. Accra: Project Focus Ltd.

Barna, László. 2013. Assessing the importance of project management soft competencies in an IT and telecommunication company. Theory, Methodology, Practice 9: 17.

Bartoška, Jan, Martin Flégl, and Martina Jarkovská. 2012. IPMA standard competence scope in project management education. International Education Studies 5: 167-76. [CrossRef]

Bokor, Michael J. K. 2011. The Dirty Politics of Development Project Hurts. Available online: http://www.ghanaweb.com/ GhanaHomePage/features/artikel.php?ID=215290 (accessed on 6 March 2020).

Bourne, Lynda, and Derek H. T. Walker. 2004. Advancing project management in learning organizations. The Learning Organization 11: 226-43. [CrossRef]

Bureau of Labor Statistics. 2005. Occupational Safety and Health Statistics: New Data for a New Century; Washington, DC: U.S. Department of Labor. Available online: https:/ / www.bls.gov/opub/mlr/2005/10/art1full.pdf (accessed on 11 March 2020).

Cannon, James A. 1994. Why IT applications succeed or fail: The intersection of technical and organizational factors. Industrial and Commercial Training 26: 10-15. [CrossRef]

Chan, Albert P. C., David Scott, and Ada P. L. Chan. 2004. Factors affecting the success of a construction project. Journal of Construction Engineering Management 130: 153-55. [CrossRef]

Cleland, David I., and Roland Gareis. 2006. Global Project Management Handbook, 2nd ed. New York: McGraw-Hill Print.

Covey, Stephen. R. 2004. The five pillars of organizational excellence. Paper presented at the ASQ Annual Quality Congress Proceedings, Milwaukee, WI, USA, June 2-9; vol. 58, p. 191.

Crawford, Lynn. 2005. Senior management perceptions of project management competence. International Journal of Project Management 23: 7-16. [CrossRef]

Drucker, Peter F. 1959. Landmarks of Tomorrow. New York: Harper.

Fong, Nai K., Lou Y. Wong, and Ling T. Wong. 2006. Fire services installation related contributors of construction delays. Building and Environment 41: 211-22. [CrossRef] 
Forcada, Nuria, Miquel Casals, Marta Gangolells, Xavier Roca, and Alba Fuertes. 2008. Experiences of success in industrial plant projects. Revista Ingeniería de Construcción 23: 82-89. [CrossRef]

García-Piqueres, Gema, Ana-M. Serrano-Bedia, and Marta Pérez-Pérez. 2019. Knowledge management practices and innovation outcomes: The moderating role of risk-taking and proactiveness. Administrative Sciences 9: 75. [CrossRef]

Hölzle, Katharina. 2010. Designing and implementing a career path for project managers. International Journal of Project Management 28 : 779-86. [CrossRef]

Ibenta, Steve N. O. 2012. Research Monograph: Guidelines for Seminar Papers, Theses Project Reports. Nigeria: Mount Carmel Publishers.

Igielski, Michal. 2014. Participation of knowledge workers at the implementation of projects in Polish enterprises. Management 18: 213-26. [CrossRef]

Ika, Lavagnon A. 2012. Project management for development in Africa: Why projects are failing and what can be done about it. Project Management Journal 43: 27-41. [CrossRef]

Ika, Lavagnon, and Damian Hodgson. 2010. Towards a critical perspective in international development project management. Paper presented at the Making Projects Critical 5, Bristol Business School, Bristol, UK, January 14-15.

International Project Management Association. 2006. IPMA Competence Baseline. version 3.0. Nijkerk: International Project Management Association.

Jałocha, Beata, Hans Petter Krane, Anandasivakumar Ekambaram, and Grażyna Prawelska-Skrzypek. 2014. Key competences of public sector project managers. Procedia-Social and Behavioral Sciences 119: 247-56. [CrossRef]

Jekale, Wubishet. 2004. Performance for Public Construction Projects in Developing Countries: Federal Road and Educational Building Projects in Ethiopia. Trondheim: Norwegian University of Science \& Technology, p. 3.

Kalodimos, Jonathan. 2017. Internal governance and performance: Evidence from when external discipline is weak. Journal of Corporate Finance 43: 193-216. [CrossRef]

Kerzner, Harold. 2000. Applied Project Management: Best Practices on Implementation. New York: John Wiley \& Sons, Inc.

Klakegg, Ole Jonny. 2016. Project risk management: Challenge established practice. Administrative Sciences 6: 21. [CrossRef]

Long, Le-Hoai, Young Dai Lee, and Jun Yong Lee. 2008. Delays and cost overrun in Vietnam large construction projects: A comparison with other selected countries. KSCE Journal of Civil Engineering 12: 367-77.

Lozano-Torró, Alicia, Tatiana García-Segura, Laura Montalbán-Domingo, and Eugenio Pellicer. 2019. Risk management as a success factor in the international activity of Spanish engineering. Administrative Sciences 9: 15. [CrossRef]

Ly, Esther, Chimay Anumba, and Patricia Carrillo. 2005. Knowledge management practices of construction project managers. Paper presented at the 21st Annual ARCOM Conference, SOAS, University of London, Association of Researchers in Construction Management, Bristol, UK, September 7-9; Edited by Farzad Khosrowshahi. vol. 1, pp. 517-26.

Lyons, Paul. 2003. Influencing performance improvement using skills charting. Journal of European Industrial Training 27: 398-404. [CrossRef]

Madter, Nancy, Denise A. Bower, and Bernard Aritua. 2012. Projects and personalities: A framework for individualising project management career development in the construction industry. International Journal of Project Management 30: 273-81. [CrossRef]

Masterman, Jack. 2002. Introduction to Building Procurement Systems. London: Spon Press.

Michalski, Grzegorz, Małgorzata Rutkowska-Podołowska, and Adam Sulich. 2018. Remodeling of FLIEM: The cash management in Polish small and medium firms with full operating cycle in various business environments. In Efficiency in Business and Economics. Cham: Springer, pp. 119-32.

Morris, David. 2010. Are teachers technophobes? Investigating professional competency in the use of ICT to support teaching and learning. Procedia-Social and Behavioral Sciences 2: 4010-15. [CrossRef]

Muo, Ik. 2013. Motivating \& managing knowledge workers: Evidences from diverse industries \& cultures. Journal Management. E Sustainability 3: 119-31.

Murch, Richard. 2001. Project Management: Best Practices for IT Professionals. Upper Saddle River: Prentice Hall, Inc.

Ofori, Daniel F. 2013. Project management practices and critical success factors: A developing country perspective. International Journal of Business and Management 8: 14-31. [CrossRef]

Ofori-Kuragu, Joseph K., De-Graft Owusu-Manu, and Joshua Ayarkwa. 2016. The case for the construction industry council, Ghana. Journal of Construction in Developing Countries 21: 131-49. [CrossRef]

Olateju, Olawale I., Ibraheem A. Abdul-Azeez, and Salimonu A. Alamutu. 2011. Project management practice in Nigerian public sector: An empirical study. Australian Journal of Business and Management Research 1: 1.

Olomolaiye, Anthony, and Charles O. Egbu. 2004. Motivating knowledge workers: The dilemma of HRM's contribution to knowledge management in the construction industry. Paper presented at the 1st International Salford Centre for Research and Innovation (SCRI) Research Symposium, University of Salford, Salford, UK, March 30-31.

Osei-Kyei, Robert, and Albert P. C. Chan. 2017. Comparative analysis of the success criteria for public-private partnership projects in Ghana and Hong Kong. Project Management Journal 48: 80-92.

Othman, Ezzat, and Ayman Ahmed. 2013. Challenges of mega construction projects in developing countries. Organization, Technology $\mathcal{E}$ Management in Construction: An International Journal 5: 730-46.

Project Management Institute. 2002. Project Management Competency Development (PMCD) Framework. Pennsylvania: Project Management Institute Inc. 
Project Management Institute. 2008. A Guide to the Project Management Book of Knowledge (PMBOK), 4th ed. Newtown Square: Project Management Institute Inc.

Project Management Institute. 2013. A Guide to the Project Management Book of Knowledge (PMBOK), 5th ed. Newtown Square: Project Management Institute Inc.

Project Management Institute. 2017. A Guide to the Project Management Book of Knowledge (PMBOK), 6th ed. Newtown Square: Project Management Institute Inc.

Rahman, Rahimi A., and Steven K. Ayer. 2017. Prevalent issues in BIM-based construction projects. Paper presented at the Proceedings of Joint Conference on Computing in Construction, Heraklion, Greece, July 4-7; vol. 1, pp. 645-52.

Rondinelli, Dennis A. 1993. Development Projects as Policy Experiments: An Adaptive Approach to Development Administration. London: Psychology Press.

Sebt, Mohammad Hassan, Vahid Shahhosseini, and Mohammad Rezaei. 2010. Competency based optimized assignment of project managers to projects. Paper presented at the 12th UKSim, International Conference on Computer Modelling and Simulation, Cambridge, UK, March 24-26; vol. 12, pp. 311-16.

Serrat, Olivier. 2017. Managing knowledge workers. In Knowledge Solutions. Singapore: Springer.

Thal, Alfred E., Jr., and John D. Bedingfield. 2010. Successful project managers: An exploratory study into the impact of personality. Technology Analysis \& Strategic Management 22: 243-59.

Turriago-Hoyos, Alvaro, Ulf Thoene, and Surendra Arjoon. 2016. Knowledge workers and virtues in Peter Drucker's management theory. SAGE Open 6: 1-9. [CrossRef]

Twumasi-Ampofo, Kwadwo, Ernest Osei-Tutu, Isaac Decardi-Nelson, and Prince Abrokwa Ofor. 2014. A model for reactivating abandoned public housing projects in Ghana. Civil and Environment Research 6: 6-16.

Williams, Sunday. 2011. Nigeria: The Country's Projects Are Poorly Conceptualized. Available online: http://allafrica.com/stories/20 1106300686.html (accessed on 17 January 2020). 